\title{
Hubungan Budaya dengan Keselamatan Pasien di Rumah Sakit
}

\author{
Cindy Minannisa
}

\section{cindyminannisa01@gmail.com}

\begin{abstract}
Abstrak
Budaya keselamatan pasien berhubungan langsung dengan sikap dan motivasi individu untuk melaporkan adanya insiden keselamatan pasien. Sikap keterbukaan untuk melaporkan adanya insiden oleh individu merupakan salah satu indikator internalisasi budaya keselamatan pasien dalam perilaku individu. Sikap yang tidak mendukung pelaporan insiden pada staf terutama pada perawat akan menghambat upaya menciptakan pelayanan yang aman karena ketiadaan laporan insiden akan berdampak pada rumah sakit tidak mengetahui adanya peringatan potensial akan adanya bahaya yang dapat menyebabkan error. Tujuan: untuk mengetahui bagaimana hubungan budaya terhadap keselamatan pasien di rumah sakit. Metode: Tugas ini menggunakan metode Literature review dimana dilakukan dengan cara menganalisis kajian dan eksplorasi jurnal, text book, maupun e-book yang relevan dan membahas tentang hubungan budaya terhadap keselamatan pasien di rumah sakit. Hasil: Hasil dari pengkajian ini dengan menggunakan metode literatur review adalah dengan membaca pengkajian ini pembaca dapat menegetahui berapa penting hubungan budaya terhadap keselamatan pasien di rumah sakit.
\end{abstract}

\section{Kata Kunci: Budaya, Keselamatan, Rumah Sakit}

\section{Latar Belakang}

Pada saat ini upaya untuk meningkatkan mutu pelayanan dan rneningkatkan upaya keselamatan pasien di rumah sakit sudah merupakan sebuah gerakan universal. Berbagai negara maju bahkan telah menggeser paradigma "quality" kearah paradigma baru Quality-safety yang mengandung arti tidak hanya meningkatkan mutu pelayanan, namun yang lebih penting adalah menjaga keselamatan pasien secara konsisten dan terus menerus. Keselamatan (safety) telah menjadi isu global termasuk juga untuk rumah sakit. Terdapat lima isu penting yang terkait dengan keselamatan (safety) di rumah sakit dan keselamatan pasien (patient safety) merupakan salah satunya. Kelima aspek keselamatan tersebut sangatlah penting untuk dilaksanakan disetiap rumah sakit. Namun harus diakui kegiatan institusi rumah sakit dapat berjalan apabila ada 
pasien, sehingga keselamatan pasien merupakan prioritas utama untuk dilaksanakan dan hal tersebut terkait dengan isu, mutu dan citra perumah sakitan.

Rumah sakit sebagai organisasi badan usaha di bidang kesehatan mempunyai peranan penting dalam mewujudkan derajat kesehatan masyarakat secara optimal. Oleh karena itu rumah sakit dituntut agar mampu mengelola kegiatannya dengan mengutamakan pada tanggung jawab para professional di bidang kesehatan, khususnya tenaga medis dan tenaga keperawatan dalam menjalankan tugas dan kewenangannya. Membangun budaya keselamatan pasien merupakan langkah awal dalam pengembangan keselamatan pasien. Budaya keselamatan pasien di rumah sakit merupakan bagian dari budaya organisasi, sehingga diperlukan untuk meningkatkan pelayanan kerja perawat.

Keselamatan rumah sakit saat ini telah menjadi isu global. Terdapat lima komponen penting yang terkait dengan keselamatan rumah sakit yang salah satunya adalah keselamatan pasien. Keselamatan pasien dipengaruhi oleh bagaimana budaya individu dan sistem yang berjalan di dalam organisasi tersebut. Keselamatan pasien adalah suatu sistem yang membuat asuhan pasien lebih aman, meliputi asessmen risiko, identifikasi dan pengelolaan risiko pasien, pelaporan dan analisis insiden, kemampuan belajar dari insiden dan tindak lanjutnya, serta implementasi solusi untuk meminimalkan timbulnya risiko dan mencegah terjadinya cedera yang disebabkan oleh kesalahan akibat melaksanakan suatu tindakan atau tidak mengambil tindakan yang seharusnya diambil. Insiden keselamatan pasien adalah setiap kejadian yang tidak disengaja dan kondisi yang mengakibatkan atau berpotensi mengakibatkan cedera yang dapat dicegah pada pasien.

Keselamatan pasien dipengaruhi oleh bagaimana budaya individu dan sistem yang berjalan di dalam organisasi tersebut. Sehingga harus dilakukan pendekatan secara personal/individu maupun sistem manajemen di dalam institusi tersebut. Budaya keselamatan di berbagai Industri berkembang sangat pesat. Angka kecelakaan kerja menurun karena didukung oleh kesadaran akan arti pentingnya nilai keselamatan dalam organisasi.

Sebuah penelitian mengungkapkan bahwa keberhasilan pelaksanaan program keselamatan pasien oleh petugas rumah sakit dipengaruhi oleh beberapa hal, salah satu nya adalah budaya keselamatan pasien. Penelitian Nygren et al (2013) mengungkapkan bahwa 
budaya keselamatan pasien menjadi faktor pendukung dalam pelaksanaan program keselamatan pasien. Budaya keselamatan pasien akan memotivasi petugas untuk melaporkan setiap insiden keselamatan pasien yang terjadi. Dalam upaya meminimalisir terjadinya KTD yang terkait dengan aspek keselamatan pasien maka manajemen rumah sakit perlu menciptakan adanya budaya keselamatan pasien yang harus diterapkan dalam seluruh lingkup rumah sakit.

\section{Metode}

Metode yang saya gunakan adalah Literature review dimana dilakukan dengan cara menganalisis kajian dan eksplorasi jurnal, text book, maupun e-book yang relevan dan membahas tentang hubungan budaya terhadap keselamatan pasien di rumah sakit. Dengan metode ini informasi pembahasan mengenai hubungan budaya terhadap keselamatan pasien di rumah sakit dapat dihami. Sumber yang digunakan bersifat subjektif yaitu proses penulisan yang lebih fokus pada landasan teori. Dan melakukan analisis buku dan e-jurnal yang relevan dan berfokus kepada pengaplikasian berfikir kritis dalam mengelola informasi dan komunikasi keperawatan. Sumber yang digunakan adalah sumber yang diterbitkan di 8 tahun terakhir dan referensi akan dicantumkan dibagian daftar pustaka.

\section{Hasil}

Menciptakan budaya keselamatan pasien merupakan hal yang sangat penting. Hal tersebut dikarenakan budaya mengandung 2 komponen yaitu nilai dan keyakinan di mana nilai mengacu pada suatu yang diyakini oleh anggota organisasi untuk mengetahui apa yang benar dan apa yang salah sedangkan keyakinan mengacu pada sikap tentang cara bagaimana seharusnya bekerja dalam organisasi.

Budaya keselamatan pasien merupakan langkah utama dalam meningkatkan keselamatan pasien. Pemimpin merupakan motor penggerak untuk melakukan aktifitas sesuai dengan yang diharapkan organisasi. Promosi budaya keselamatan pasien yang baik merupakan pelaksanaan dari intervensi yang mendasar dari kepemimpinan yang akan merubah perilaku anggota tim(Weaver et al., 2013).

Budaya keselamatan pasien yang ada dirumah sakit memiliki hubungan langsung terhadap pelaksanaan pelayanan yang bertujuan untuk menjamin keselamatan pasienyang secara 
keseluruhan akan mempengaruhi kinerja individu dalam mengimplementasikan nilai-nilai yang mendukung keselamatan pasien. Keselamatan pasien dapat dilihat melalui indikator rendahnya angka insiden keselamatan pasien. Salah satu perilaku yang diharapkan dari individu adalah keterbukaan melaporkan terjadinya insiden. Budaya keselamatan pasien dikatakan berhasil apabila semua elemen yang ada didalam rumah sakit menerapkan budaya keselamatan pasien dalam pekerjaannya sehari-hari (Reiling, 2009).

Hasil penelitian menunjukkan bahwa keterbukaan komunikasi mempunyai pengaruh yang signifikan terhadap sikap melaporkan insiden. Budaya keterbukaan dalam organisasi akan mendorong timbulnya perasaan didukung pada tenaga professional jika ada sesuatu yang salah yang akan menimbulkan kepercayaan diri untuk bertindak dengan tepat. Sikap terbuka antar tenaga profesional dapat ditunjukkan melalui perilaku mengakui, meminta maaf dan menjelaskan ketika sesuatu yang salah telah terjadi, melakukan penyelidikan yang menyeluruh untuk mencegah masalah terulang, memberikan dukungan bagi mereka yang terlibat untuk mengatasi konsekuensi fisik dan psikologis yang terjadi. Menurut Najihah (2018) dengan melakukan pelaporan insiden keselamatan pasien dapat meningkatkan penerapan budaya keselamatan pasien sehingga insiden keselamatan pasien tersebut dapat dihindari.

Dengan meningkatnya budaya keselamatan pasien maka angka kejadian insiden keselamatan pasien dapat diminimalkan. Salah satu upaya yang dapat dilakukan untuk meningkatkan penerapan budaya keselamatan pasien untuk meminimalkan insiden keselamatan pasien adalah dengan melakukan pelaporan insiden keselamatan pasien, baik kejadian nyaris cedera (KNC), kejadian potensial cedera( KPC), kejadian tidak cedera (KTC) apalagi kejadian tidak diharapkan (KTD).

\section{Pembahasan}

Keselamatan Pasien adalah suatu sistem yang membuat asuhan pasien lebih aman, meliputi asesmen risiko, identifikasi dan pengelolaan risiko pasien, pelaporan dan analisis insiden, kemampuan belajar dari insiden dan tindak lanjutnya, serta implementasi solusi untuk meminimalkan timbulnya risiko dan mencegah terjadinya cedera yang disebabkan oleh kesalahan akibat melaksanakan suatu tindakan atau tidak mengambil tindakan yang seharusnya diambil. Keselamatan pasien adalah prioritas utama dan harus segera dilaksanakan di rumah 
sakit karena dapat menyebabkan cedera langsung kepada pasien, juga terkait dengan kualitas dan citra rumah sakit serta standar pelayanan yang harus dipenuhi oleh rumah sakit itu terkait dengan versi 2012 dari standar akreditasi mengacu pada Joint Commission International (JCI).

Perawat adalah pejabat eksekutif kesehatan dengan waktu kerja tertinggi yang memberikan 24 jam pelayanan terus menerus serta harus berkolaborasi dengan tim kesehatan lain dan oleh karena itu lahhal tersebut dapat menyebabkan atau berisiko terjadinya Insiden Keselamatan Pasien1. Selain itu, perawat memiliki peran yang paling dominan dalam mencegah terjadinya kesalahan dalam pengobatan, termasuk pelaporan insiden, mendidik diri sendiri dan orang lain. Sejalan dengan definisi keperawatan ANA 2003 yang menyatakan bahwa keperawatan adalah perlindungan, promosi, dan optimalisasi kesehatan dan kemampuan, pencegahan penyakit dan cedera, pengentasan penderitaan melalui diagnosis dan pengobatan respon manusia, dan advokasi dalam perawatan individu, keluarga, masyarakat, dan populasi.

Oleh sebab itu peran perawat dalam mengimplementasikan asuhan keperawatan dan mewujudkan keselamatan pasien di rumah sakit dapat dirumuskan sebagai berikut, perawat harus mematuhi standar layanan dan SOP yang telah ditetapkan, menerapkan prisip etik dalam meberikan asuhan keperawatan, memberikan pendidikan kepada pasien dan keluarga pasien tentang asuhan keperawatan yang sedang dijalankan, selalu bekerjasama dengan tim kesehatan yang lainnya dalam memberikan asuhan keperawatan, menerapkan komunikasi yang baik terhadap sejawat, pasien dan keluarga, selalu proaktif dan peka dalam setiap menyelesaikan kejadian atau insiden yang berkaitan dengan keselamatan pasien, mendokumentasikan segala bentuk kegiatan yang ada hubungannya dengan asuhan keperawatan yang dilakukan kepada pasein.

Seorang antropolog Inggris bernama E.B Taylor mendefinisikan budaya sebagai sesuatu kompleks yang mencakup pengetahuan kepercyaan, kesenian, moral, hukum, adat istiadat dan lainnya yang didapatkan oleh manusia sebagai anggota masyarakat. Budaya keselamatan pasien adalah pola terpadu perilaku individu dan organisasi dalam memberikan pelayanan yang aman dan bebas dari cedera. Budaya keselamatan adalah output dari individu dan kelompok terhadap nilai-nilai, sikap, kompetensi, dan pola dan kebiasaan yang mencerminkan komitmen dan gaya dan kemampuan organisasi dan manajemen keselamatan kesehatan. Budaya keselamatan pasien merupakan suatu hal yang pentingkarena membangun budaya keselamatan pasien merupakan 
suatu cara untukmembangun program keselamatan pasien secara keseluruhan, karena apabila kita lebih fokus pada budaya keselamatan pasien maka akan lebih menghasilkan hasil keselamatan yang lebih apabila dibandingkan hanya menfokuskan pada programnya saja.

Beginta (2012) mengatakan bahwa upaya yang dapat dilakukan untuk meningkatkan budaya keselamatan adalah dengan mendorong setiap orang bertanggung jawab akan keselamatan terhadap diri sendiri, rekan kerja, pasien, dan pengunjung, mengutamakan keselamatan dan keuntungan di atas keutungan dan tujuan organisasi. Budaya keselamatan pasien merupakan langkah utama dalam meningkatkan keselamatan pasien.

Dari jurnal (Najihah.2018. Budaya Keselamatan Pasien Dan Insiden Keselamatan Pasien Di Rumah Sakit: Literature Review. Volume 3 Nomor 1, Juli ) Penerapan budaya keselamatan pasien yang adekuat akan menghasilkan pelayanan keperawatan yang bermutu. Pelayanan kesehatan yang bermutu tidak cukup dinilai dari kelengkapan teknologi, sarana prasarana yang canggih dan petuugas kesehatan yang profesional, namun juga ditinjau dari proses dan hasil pelayanan yang diberikan (Ilyas, 2004).

Keselamatan pasien adalah sebuah transformasi budaya, dimana budaya yang diharapkan adalah budaya keselamatan, budaya tidak menyalahkan, budaya lapor dan budaya belajar. Membangun budaya keselamatan pasien merupakan elemen penting untuk meningkatkan keselamatan pasien dan kualitas pelayanan. Penilaian budaya keselamatan pasien di rumah sakit dapat dilakukan dengan menilai dimensi-dimensi yang terkait dengan budaya keselamatan pasien. Penilaian terhadap budaya keselamatan merupakan permulaan dari proses pengembangan program keselamatan pasien itu sendiri yang hasilnya dapat digunakan untuk mengidentifikasi area/unit yang akan dikembangkan, untuk evaluasi program, untuk membuat perbandingan secara internal maupun eksternal dan sebagai dasar pembuatan kebijakan (Nieva,2003). Survey budaya atau iklim keselamatan sudah menjadi pendekatan yang umum untuk memonitoring keselamatan pasien, dan berbagai jenis instrument pengukurannya terus mengalami pengembangan (Matsubara et al, 2008) dalam Rahmawati (2011). Pengukuran budaya keselamatan pasien dapat dilakukan berdasarkan dimensi yang mendasari ataupun berdasarkan tingkat maturitas dari organisasi dalam menerapkan budaya keselamatan pasien. Dikarenakan belum adanya konsensus mengenai standard pengukuran budaya keselamatan pasien, menyebabkan bervariasinya definisi, konsep maupun dimensi budaya keselamatan pasien. 
Berdasarkan hasil penelitian terhadap indikator budaya keselamatan yang meliputi kerja sama, komunikasi, kepemimpinan, pelaporan dan respon tidak menghukum terhadap kesalahandidapatkan hasil dan pembahasan sebagai berikut :

\section{Kerjasama}

Kerjasama merupakan indikator pertama dari budaya keselamatan pasien. Berdasarkan hasil dari penelitian, dalam melaksanakan asuhan keperawatan kepada pasien perawat akan selalu membutuhkan bantuan dari perawat maupun tenaga kesehatan yang lainnya. Bentuk kerjasama tidak hanya berupa saling membantu pekerjaan ketika perawat dihadapkan pada tugas yang sangat banyak dan membutuhkan penyelesaian yang sesegera mungkin, namun juga bisa berupa pembagian tugas berdasarkan kelompok kecil atau tim dalam satu unit ruang rawat inap.

\section{Komunikasi}

Komunikasi sangatlah penting dalam setiap melaksanakan tugas dalam hal ini adalah melaksanakan asuhan keperawatan pada pasien. Komunikasi yang baik dan benar perlu dilakukan untuk mengkoordinasikan asuhan keperawatan yang melibatkan banyak profesi selain

profesi perawat. Komuniasi dalam praktek keperawatan merupakan elemen penting bagi perawat dalam melaksanakan asuhan keperawatan untuk mendapatkan hasil yang optimal. Perawat memiliki peran yang paling dominan dalam mencegah terjadinya kesalahan dalam pengobatan, termasuk pelaporan insiden, mendidik diri sendiri dan perawat lain tentang penting komunikasi, memberikan rekomendasi untuk perubahan prosedur dan kebijakan serta keterlibatan dalam melakukan identifikasi permasalahan.

Informasi tentang keselamatan pasien perlu diketau oleh semua perawat yang memberikan asuhan keperwatan hal tersebut berfungsi untuk mencegah perawat melakukan tindakan yang dapat menyebabkan cidera pada pasien. Komunikasi adalah kunci sukses berinteraksi dalam kehidupan berorganisasi. Ketika komuniksai efektif, arus informasi dalam organisasi yang dinamis akan berjalan lancar sehingga mempercepat proses tercapainya tujuan organisasi.

\section{Kepemimpinan}

Pemimpin harus memiliki komitmen yang kuat terhadap keselamatan pasien, sehingga keselamatan pasien menjadi hal yang utama dalam memberikan pelayanan keperawatan. Pemimpin harus mampu menjadi agen perubahan bagi anak buahnya dengan melaksanakan program keselamatan pasien. Pimpinan mendorong dan menjamin implementasi program 
keselamatan pasien secara terintegrasi. Pemimpin harus membangun komitmen dan fokus yang kuat dan jelas guna mendukung staff untuk menjalankan program keselamatan pasien secara berkesinambungan, memprioritaskan atau mengintegrasikan program keselamatan pasien dalam setiap rapat dengan para pengambil keputusan, mengagendakan pelatihan tentang keselamatan pasien bagi semua staf secara berkala dan berkesinambungan.

Pimpinan mengukur dan mengkaji efektifitas kontribusinya dalam meningkatkan kinerja rumah sakit dan keselamatan pasien. Pemimpin harus mampu memotivasi bawahannya, salah satunya dengan pujian. Pujian yang diberikan oleh pemberi kerja pada saat pekerjaan yang selesai dilakukan sesuai dengan prosedur yang ditetapkan akan memberikan motivasi tersendiri untuk perawat.

\section{Pelaporan}

Indikator pelaporan dalam penerapan budaya keselamatan pasien berada dalam kategori cukup. Perawat diharuskan melaporkan kejadian kesalahan yang tidak disengaja dan kondisi yang mengakibatkan atau berpotensi mengakibatkan cedera yang dapat dicegah pada pasien, yang terdiri dari kejadian tidak diharapkan, kejadian nyaris cedera, kejadian tidak cedera dan kejadian potensial cedera. Sejatinya pelaporan insiden keselamatan pasien sangat dibutuhkan oleh semua pihak guna perbaikan pelayanan dalam hal ini khususnya asuhan keperawatan. Informasi dari pelaporan insiden keselamatan pasien yang akurat dan jelas dapat membantu identifikasi akar permasalahan bagaimana insiden tersebut bisa terjadi serta identifikasi faktor risiko sehingga insiden yang sama dapat dicegah untuk kemudian hari. Peran dan fungsi perawat yang salah satunya yaitu peran sebagai peneliti.

\section{Respon Tidak Menghukum terhadap Kesalahan}

Indikator respon tidak menghukum terhadap kesalahan ini menunjukkan bahwa dimasa yang akan datang pelaporan terhadap insiden keselamatan pasien tidak semata-mata hanya berupa pelaporan insiden keselamatan, namun pelaporan tersebut hendaknya ditindaklanjuti guna memperbaiki kesalahan dan mencari akar permasalahan, tidak untuk menghukum perawat yang melakukan kesalahan atau berpengaruh terhadap penilainan kinerjanya. Sebagaimana diatur dalam Peraturan Menteri Kesehatan Republik Indonesia nomer 755/Menkes/Per/IV/2011 tentang pelaksanaan komite medis di rumah sakit bahwa audit medis dilakukan dengan memprioritaskan semua staf untuk menghilangkan blaming (menyalahkan), naming (menyebut atau mencari siapa yang salah), dan shaming (mempermalukan atau mengakui kesalahan). Untuk mampu belajar 
dari kesalahan harus ditekankan pada upaya mencari apa yang salah, mengapa kesalahan tersebut dapat terjadi, dan apa yang bisa dilakukan untuk memperbaiki kesalahan.

\section{Penutup}

Keselamatan pasien (patient safety) pada dasarnya merupakan sebuah konsep dalam dunia medis yang terus berkembang . Menurut Rojovsky (2005) keselamatan pasien didefinisikan sebagai upaya maksimal yang dilakukan rumah sakit dalam rangka memberikan pelayanan kepada pasien melalui penerapan metode dan regulasi yang legal serta melalui standar yang terukur untuk meminimalisir kesalahan medis.

Budaya keselamatan adalah nilai, keyakinan, perilaku yang dianut individu dalam suatu organisasi mengenai keselamatan yang memprioritaskan dan mendukung peningkatan keselamatan. Budaya keselamatan pasien merupakan nilai, sikap, persepsi, kompetensi dan pola perilaku individual dan kelompok yang menentukan komitmen dan cara organisasi dalam keselamatan pasien (Nivalinda, et al, 2013). Budaya keselamatan pasien merupakan kewajiban dan tanggung jawab seluruh pegawai. Pegawai adalah bagian dari organisasi merupakan ujung tombak dalam budaya keselamatan pasien (Amarapathy, Sridharan, Perera, \& Handa, 2013).

Budaya keselamatan pasien di suatu rumah sakit dapat diketahui dengan melakukan kajian evaluasi yaitu untuk mengetahui seberapa jauh budaya keselamatan pasien di suatu rumah sakit. Menurut Agency of Healthcare Research and Quality (AHRQ) dalam menilai budaya keselamatan pasien di rumah sakit terdapat beberapa aspek dimensi yang perlu diperhatikan yaitu harapan dan tindakan manajer dalam mempromosikan keselamatan pasien, pembelajaran berkelanjutan, kerja sama dalam unit, keterbukaan komunikasi, umpan balik terhadap kesalahan, respon tidak menyalahkan, staf yang adekuat, persepsi secara keseluruhan, dukungan manajemen, kerja sama tim antar unit, pemindahan pasien, dan frekeunsi pelaporan.

\section{DAFTAR PUSTAKA}

Agustina Pujilestari, A. M. (2014, Maret). BUDAYA KESELAMATAN PASIEN DI INSTALASI RAWAT INAP RSUP DR. WAHIDIN SUDIROHUSODO KOTA MAKASSAR. JURNAL MKMI, 10(1), 57-64. 
Buhari, B. (2019, Februari). BUDAYA KESELAMATAN PASIEN RUMAH SAKIT PEMERINTAH DAN RUMAH SAKIT SWASTA DI KOTA JAMBI. Jurnal 'Aisyiyah Medika, 3(1), 1-18.

Dewi Anggraeni, A. M. (2016). Pengaruh Budaya Keselamatan Pasien terhadap Sikap Melaporkan Insiden pada Perawat di Instalasi Rawat Inap Rumah Sakit Tk. II dr. Soepraoen. Jurnal Aplikasi, 14(2), 309-321.

Essy Mandriani, H. H. (2019). Analisis Dimensi Budaya Keselamatan Pasien Oleh Petugas Kesehatan di RSUD dr Rasidin Padang Tahun 2018. Jurnal Kesehatan Andalas, 8(1), 131-137.

Herawati, Y. T. (2015, Maret). BUDAYA KESELAMATAN PASIEN DI RUANG RAWAT INAP RUMAH SAKIT X KABUPATEN JEMBER. Jurnal IKESMA, 11(1), 52-60.

Mei Rani Wulandari, S. Y. (2019, November). Peningkatan Budaya Keselamatan Pasien Melalui Peningkatan Motivasi Perawat dan Optimalisasi Peran Kepala Ruang. Jurnal Kepemimpinan dan Manajemen Keperawatan, 2(2), 58-66.

Mudayana, A. A. (2014, Maret). PERAN ASPEK ETIKA TENAGA MEDIS DALAM PENERAPAN BUDAYA KESELAMATAN PASIEN DI RUMAH SAKIT. Supplemen Majalah Kedokteran Andalas, 37(1), 69-74.

Simamora, R. H. (2018). Buku ajar keselamatan pasien melalui timbang terima pasien berbasis komunikasi efektif: SBAR. Medan: USUpress.

Simamora, R. H. (2020). Learning of Patient Identification in Patient Safety Programs Through Clinical Preceptor Models. Medico Legal Update, 20(3), 553-556.

Tio Dora Ultaria S, S. P. (2017, Januari). GAMBARAN BUDAYA KESELAMATAN PASIEN DI RS ROEMANI MUHAMADDIYAH SEMARANG. JURNAL KESEHATAN MASYARAKAT (e-Journal), 5(1), 118-125.

Yeni Yarnita, M. (2019, Juli). BUDAYA KESELAMATAN PASIEN PADA PERAWAT DI INSTALASI PERAWATAN INTENSIVE RSUD ARIFIN ACHMAD PROVINSI RIAU. Jurnal Keperawatan Priority, 2(2), 109-119. 
Yulia Yasmi, H. T. (2018, Februari). Faktor-Faktor yang Berhubungan dengan Budaya Keselamatan Pasien di Rumah Sakit Karya Bhakti Pratiwi Bogor Tahun 2015. Jurnal Administrasi Rumah Sakit (ARSI), 4(2), 98-109. 